\title{
Traders Perception and Awareness on Financial Derivatives in Indian Stock Market
}

\author{
N. Selvaraj: Saraswathi Narayanan College, Madurai, India.
}

\begin{abstract}
The Government of India has introduced Economic Policy in 1991 to implement structural reforms for reduce the imbalances. In India, Traders want maximum gain with minimum risk, so is the case with derivatives. Derivatives are among the forefront of the innovations in the financial markets and aim to increase returns and reduce risk. A derivative is a financial product which has been derived from another financial product or commodity. The derivatives do not have independent existence without underlying product and market. Derivatives are contracts which are written between two parties for easily marketable assets. Derivatives are gaining importance due to increased volatility in capital and foreign currency markets. RBI finds ways for healthy development of market and takes steps to popularise the use of derivative instruments, but still awareness about the derivative instruments and its uses are quite low. Hence, it is necessary to find out the level of awareness among investing public and if found low, how to create adequate awareness to encourage the use of derivative products as hedge tools. This study can be used by the regulating authorities and broker houses to increase awareness among the traders about derivatives. One should invest in secured and risk-free investments rather than high-risk, highly profitable investments. Tracking the market environment better with sound knowledge about a particular stock would result in better returns. Since many of the entities in this study are independent of each other, there is need to analyse on a buying decision specifically for respective stocks. People with less experience can also be high profit makers when decisions are based on intricate fundamental and technical analyses.
\end{abstract}

Key words: Derivatives, Stock market, Financial, Traders, Investment.

\section{Introduction}

Before liberalization, Indian economy was strongly controlled by number of measures like licensing system, high tariffs and rates, limited investment in core sectors. The Indian economy growth is highly unsustainable because of its dependence on borrowings to correct the current account deficit during the period of $1980^{\circ e} \mathrm{~s}$. The Government of India has introduced Economic Policy in 1991 to implement structural reforms for reduce the imbalances. At that time, the financial sector was much unstructured and its scope was limited only to bonds, equity, insurance, commodity markets, mutual and pension funds. In order to structure the security market, a regulatory authority named as SEBI (Security Exchange Board of India) was introduced and first electronic exchange National Stock Exchange also set up. The purpose behind this was to regularize the investments, mobilization of resources and to give the credit (Sehgal, Sood, \& Rajput, 2009).

\section{Statement of the Problem}

In India, Traders want maximum gain with minimum risk, so is the case with derivatives. Derivatives are among the forefront of the innovations in the financial markets and aim to increase returns and reduce risk. A 
derivative is a financial product which has been derived from another financial product or commodity. The derivatives do not have independent existence without underlying product and market. Derivatives are contracts which are written between two parties for easily marketable assets. It is derived by the means of a mutual agreement, the types of derivative products are limited only by imagination and so there is no definitive list of derivative products. Forward market, future market, option and swaps are the basic types of derivatives. A forward contract is an agreement to buy or sell an asset on a specified date for a specified price. The forward contracts are normally traded outside the exchanges and is present in India from long time back, but future option have emerged in few years in financial market and has brought improvement from the forward market as they are traded on exchange, therefore there is more transparency and less risk. A futures contract is a standardized contract, traded on a futures exchange, to buy or sell a certain underlying instrument at a certain date in the future, at a pre-set price. And a futures contract gives the holder the right and the obligation to buy or sell, which differs from an options contract.

The trading of derivative securities commenced in India after much debate over the introduction of derivatives to hedge the risks posed by the securities and a long waiting period. The National Stock Exchange (NSE) sought permission from the Securities and Exchange Board of India (SEBI) to trade stock index futures in December 1995, but it was only after five years that the first derivative security, i.e., stock index futures, was traded on the exchange. Stock index futures were introduced in June 2000, and thereafter, stock index options in June 2001. The options and futures on individual shares were introduced in July 2001 and November 2001, respectively. Later, more indices and shares were added in this segment. (Table I exhibits chronology of events relating to the development of derivative market in India.) As on December 31, 2009, there were 179 individual shares for which futures and options were traded. They are traded on the Bombay Stock Exchange (BSE) and the National Stock Exchange (NSE) wherein the latter contributes to more than 95 per cent of the total turnover in the derivative market in India (Srivastava \& Jain, 2008).

Derivatives are gaining importance due to increased volatility in capital and foreign currency markets. RBI finds ways for healthy development of market and takes steps to popularise the use of derivative instruments, but still awareness about the derivative instruments and its uses are quite low. Hence, it is necessary to find out the level of awareness among investing public and if found low, how to create adequate awareness to encourage the use of derivative products as hedge tools.

Financial derivatives were introduced as a risk management tool; but now they have become the most risky instruments in the markets as the experience in US markets in recent years would corroborate. Though it is widely known that derivatives can be used for hedge, extent of effectiveness has not been systematically and scientifically proved. Moreover, individual Traders are extensively using derivatives for speculation ignoring its use as a hedge tool. Hence, it is necessary to assess how far financial derivatives are effective for hedge from Traders point of view (Somanathan, 2003).

Derivative market has shown a great potential in the last few years, but the real issues are yet not been resolved. Instruments traded under derivative market and its volume of trade is also increasing day by day, but the main objective i.e. setting up of different exchanges yet not achieved. On the other hand future prospects of derivative markets are not sound because of the unresolved issues and they are framed as big challenges in the way.

The percentage of physical settlement under commodity derivatives is very less because of the Forward Contract Act, 1952. In this Act, cash settlement of outstanding contracts at maturity is disallowed. In other words, all outstanding contracts at maturity should be settled in physical delivery. To overcome this huddle participants settle their positions before maturity. This Act, needs to be adjusted which is a big challenge in front of derivative market. Regulators and Supervisory bodies are having an eye on the counter derivative market due to its rapid growth. Some OTC (Over the Counter) derivatives are taken as stress relievers in the tough time of global crisis. But the big challenge is to overcome the assumption of the critics that this market is less transparent, weaker capital requirement and systematic risk.

Derivative market requires a setting up of a regulatory system like security market which is regulated by Security Exchange Board of India which is an independent body. On other side derivative is controlled by FMC (Forward Market Commission) which depends upon the funds of Department of Consumer Affairs for the development of this market a sole powered body is required. Both the regulatory authorities" i.e. SEBI and FMC are also required to work closely for better results Competition of OTC derivatives with the Exchange traded derivatives. Advisors are having the view that this will increase the transparency, liquidity and on the

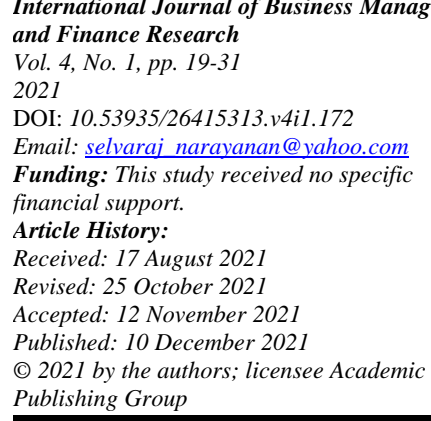


other side clearing and settlement procedure is better. All the above advices are based on the assumption that the existing method of trading in OTC products is all based on telephone trading and there is no clearing system in place. Despite the developments happening in the capital market in India and even after a decade of existence of a vibrant capital market, the equity instruments are not considered as an attractive household investment.

The recent economic recession had a great impact on stock market. The developing countries also taste the economic downtrend. The Indian economy is also not left out. Before the recession, Indian economy was moving at a faster rate because of the growth in information technology and other sectors. But after the recession the economic level comes down and there will be some velocity in the Indian stock market conditions. As the regulatory system is so strong in India, the stock market is able to withstand many odds. Since the stock market is all the time unpredictable and unstable, the Traders are all the time at very high risk. They have to consider many factors like Economic environment, Political stability, Industrial growth etc., before they invest. Though there are many studies on the stock market related areas, the information provided to the Trader and industry is not sufficient. As a result the Trader and the stock market players will be searching for required information. There are some research gaps in the existing literature relating to the stock market. Hence, the present study is aimed to study the traders" awareness and perception towards equity derivative markets in Madurai District.

\subsection{Scope of the Study}

Derivatives were widely used financial tool in the stock markets. The present study focuses only on Equity derivatives excluding other derivatives like commodity derivatives, weather derivatives, etc. Financial derivative as a hedge tool is a topic with wider scope. The present study limits its scope to measure the traders" perception and awareness on financial derivatives in Indian stock market. Even though there are different types of financial derivatives that are stock futures, stock options, index futures, index options, currency futures and the like being traded in India. The present study is mainly focuses on traders" perception and awareness towards equity derivative market in Indian stock market. The present study has adopted both primary and secondary data. Geographically, the study is limited to the Indian stock market, as all the sample respondents are from Indian stock market

\subsection{Objectives of the Study}

The following are the objectives of the present study

i. To study the existing literature related to the study area.

ii. To present the origin and growth of Equity Derivative Market in India.

iii. To analyse the demographic profile of the traders in Indian stock market

iv. To analyse the traders perception towards Equity Derivative Market in Indian stock market.

v. To offer suitable suggestions based on the findings of the study area.

\subsection{Primary Data}

The primary data were collected directly from the traders who are trading equity derivatives in the National Stock Exchange and Bombay Stock Exchange in Indian stock market through a well devised interview schedule. For data collection, the researcher has interviewed the respondents at different places including their work place. A pre- test was conducted among thirty traders in the NSE and BSE in Indian stock market. Observations are made on the individual differences in the various components of trading. The interview schedule was prepared for the respondents have been pre-tested by the researcher in person. Comments on the question were noted and after careful analysis necessary modification have been made in the interview schedule. In the course of the time, the researcher had experienced some difficulties in getting answers to some of the questions raised and suitable changes have been incorporated before finalizing the well-structured interview schedule.

\subsection{Secondary Data}

The secondary data for the study were collected from books, journals, research articles, magazines, reports, newspapers and websites that too mainly the official sites that are National Stock Exchange and

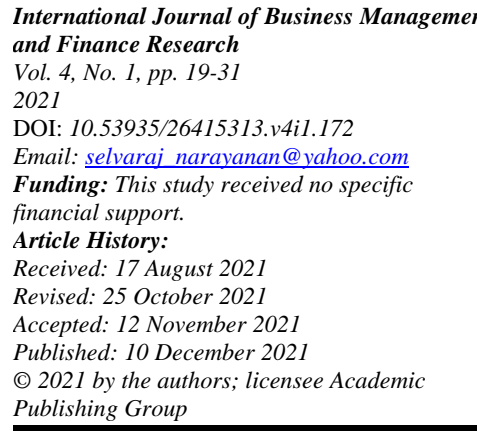


Bombay Stock Exchange in India and annual reports of SEBI. The researcher also visited various university libraries in India.

\section{Factor Analysis}

The main applications of factor analytic techniques are: (1) to reduce the number of variables and (2) to detect structure in the relationships between variables, that is to classify variables. Therefore, factor analysis is applied as a data reduction or structure detection method. The Principal component analysis is appropriate when researcher obtained measures on a number of observed variables and wishes to develop a smaller number of artificial variables (called Principal components) that will account for most of the variance in the observed variables. The principal components may then be used as predictor or criterion variables in subsequent analyses. The Principal Component Analysis with Varimax rotation for motivation was done to investigate the underlying relationships of a large number of items and to determine whether they can be reduced to a smaller set of factors. This analysis has a high potential to inflate the component loadings. Thus a higher rule-of-thumb, a cut off value of 0.40 is adopted. The Kaiser-Meyer-Olkin measure of Sampling Adequacy and Bartlett's test of Sphericity were used to determine the appropriateness of factor analysis. The Principal Component Analysis is employed for extracting factors. The Varimax rotation was used as it is centered on simplifying the columns of the factor matrix. As per the criterion only factors having Eigen values greater than one are considered significant by means of item analysis based on Pearson correlation.

Baker, Wurgler, and Yuan (2012) presented the first paper to study the international time series of the cross section of stock returns. They examined the effect of local and global component of trader sentiment for six major stock markets into one global and six local market indices for Canada, France, Germany, Japan, the United Kingdom and the United States. A validation test is conducted of Siamese Twins and results reveal that relative sentiments are correlated with the relative prices. When sentiments are high, future return is low because it" $s$ difficult to arbitrage and value stocks.

Venkatesha and Hiriyappa (2017) in their study pointed that Derivatives market is risk and return game that,,s why the trader get risk. Due to absence of delivery based settlement, many traders may not be participating in the derivatives market. Also, this could bring one more type of product in the basket to be offered to the market at large. Hence, NSE may look at starting the physical delivery derivatives contracts to give further fillip to volume on its exchange in particular and the Indian equity derivatives market at large. Traders are more often invest in index options because of derivatives are highly risky. The study suggests that Government should look forward to setting up a super regulator who can take care of these various regulatory arbitrage/risk issues or there should be joint committee of all the regulatory bodies to look into such concerns of the market from overall perspective.

\section{Framework of Analysis \\ 4.1. Factor Analysis}

The factor analysis is a technique for data reduction and that tries to explain observed relationships among multiple outcome measures as a function of some underlying variables, or factors. The factor analysis differs from other statistical analysis; it focuses on multiple dependent variables and tries to uncover patterns of relationships. In this part, the researcher has an attempt to analyse the opinion of the respondents in the study area regarding the Factors influencing the Opinion about awareness and perception towards equity derivatives by using the Factor analysis.

The factor analysis each variable is expressed as a linear combination of underlying factors. The amount of variance a variable shares with all other variables included in the analysis is referred to communality. The co- variation among the variables is described in terms of a small number of common factors plus a unique factor for each variable. These factors are not over observed. If the variables are standardized, the factor model may be represented as:

International Journal of Business Management and Finance Research 2021

DOI: 10.53935/26415313.v4i1.172

Email: selvaraj_narayanan@yahoo.com

Funding: This study received no specific

financial support.

Article History:

Received: 17 August 202

Revised: 25 October 2021

Accepted: 12 November 2021

Published: 10 December 2021

() 2021 by the authors; licensee Academic

Publishing Group
$\mathrm{X}_{\mathrm{i}}=\mathrm{A}_{\mathrm{i} 1} \mathrm{~F}_{1}+\mathrm{A}_{\mathrm{i} 2} \mathrm{~F}_{2}+\mathrm{A}_{\mathrm{i} 3} \mathrm{~F}_{3}+\ldots \ldots+\mathrm{A}_{\mathrm{im}} \mathrm{F}_{\mathrm{m}}+\mathrm{V}_{\mathrm{i}} \mathrm{U}_{\mathrm{i}}$ Where,

$\mathrm{X}_{\mathrm{i}}=\mathrm{i}^{\text {th }}$ standardized variable,

$\mathrm{A}_{\mathrm{ij}}=$ Standardized multiple regression coefficient of variable $\mathrm{i}$ on common factor $\mathrm{j}$

$\mathrm{F}=$ Common factor,

$V_{i}=$ Standardized regression coefficient of variable $\mathrm{i}$ on unique factor $\mathrm{i} \mathrm{U}_{\mathrm{i}}=$ The unique factor for variable i 
$\mathrm{m}=$ Number of common factors

The unique factors are uncorrelated with each other and with the common factors. The common factors themselves can be expressed as linear combinations of the observed variables.

$\mathrm{F}_{\mathrm{i}}=\mathrm{W}_{\mathrm{i} 1} \mathrm{X}_{\mathrm{i}}+\mathrm{W}_{\mathrm{i} 2} \mathrm{X}_{2}+\mathrm{W}_{\mathrm{i} 3} \mathrm{X}_{3}+\ldots .+\mathrm{W}_{\mathrm{ik}}+\mathrm{X}_{\mathrm{k}}$ Where,

$\mathrm{F}_{\mathrm{i}}=$ Estimate of $\mathrm{i}^{\text {th }}$ factor

$\mathrm{W}_{\mathrm{i}}=$ Weight or factor score coefficient $\mathrm{K} \quad=$ Number of variables.

It is possible to select weights or factor score coefficients so that the first factor explains the largest portion of the total variance. Then a second set of weight can be selected, so that is the second factor accounts for most of the residual variance, subject to being uncorrelated with the first factor. This same principle could be applied to selecting additional weights for the additional factors. Thus, the factors can be estimated so that their factors scores, unlike the value of the original variables, are not correlated. Furthermore, the first factor accounts for the highest variance in the data, the second factor the second highest, and so on.

\subsection{Testing the Sampling Adequacy}

For testing the sampling adequacy, before extracting the factors to test the appropriateness of the factor model, Barlett"s test of sphericity was used. The test statistic for sphericity is based on a chi-square transformation of the determinant of the correlation matrix.

Another useful statistic is Kaiser-Meyer-Olkin (KMO) test of Measuring the Sampling Adequacy. The sample values of the KMO statistic indicate that the correlation between pair of variables cannot be explained by other variables, and that factor analysis may not be appropriate. Generally, a value which is greater than .0 .5 is acceptable.

The correlation matrix was examined carefully and the two tests, viz., Barlettes test of sphericity and Kaiser- Meyer-Olkin test were undertaken to test if it was judicious to proceed with factor analysis in the present study.

The following hypothesis tested is tested by factor analysis. $\mathrm{H}_{\mathrm{o}}$ : The factor analysis is not valid $\mathrm{H}_{1:}$ The factor analysis is valid

Table-1. Reliability Statistics.

\begin{tabular}{cc}
\hline Cronbach's Alpha & N of Items \\
\hline 0.756 & 20 \\
\hline
\end{tabular}

\subsection{Factors Influencing the Opinion about Awareness and Perception towards Equity Derivative}

Table 1 shows that an examination had been made from the reliability of the data to check whether random error causing inconsistency and it turn lower reliability is at a manageable level or not, by running reliability test. From Table 1, it is clear that the values of coefficient Alpha (Cronbach's Alpha) have been obtained, the minimum value of coefficient Alpha obtained was .756. This shows data has satisfactory internal consistency reliability.

Table-2. KMO and Bartlett's Test.

\begin{tabular}{lll}
\hline Kaiser-Meyer-Olkin Measure of Sampling Adequacy. & $\mathbf{0 . 7 0 4}$ \\
\hline Bartlett's Test of Sphericity & Approx. Chi-Square & 1261.494 \\
& Df & 190 \\
& Sig. & 0.000 \\
\hline
\end{tabular}

International Journal of Business Management and Finance Research

Vol. 4 ,

DOI: $10.53935 / 26415313 . v 4 i 1.172$

Email: selvaraj_narayanan@yahoo.com

Funding: This study received no specific

financial support.

Article History:

Received: 17 August 202

Revised: 25 October 2021

Accepted: 12 November 2021

Published: 10 December 2021

(C) 2021 by the authors; licensee Academic Publishing Group
The significance (0.000) is less than the assumed value (0.05), so reject the null hypothesis, and conclude that the factor analysis is valid. Next, one may look at the kmo coefficient to cross check barlettes test. It can been seen 0.703 is more than 0.5 , so one agrees with barlette $s$ test that the factor analysis valid.

\subsection{Extraction of Factor Principal Component Analysis}

There are two main stages in factor analysis. As the first stage in the factor analysis, principal component analysis was used for the initial extraction of the factors. Pca is a technique for forming a set of new variables that are linear combinations of the original set of variables. The new variables are called principal components of factors. By retaining only the variables with eigen values greater than one, one can infer that 11.212 per 
cent of variance is explained by factor $1,11.162$ per cent of variance is explained by factor $2,8.836$ per cent of variance is explained by factor 3, 8.798 per cent of variance is explained by factor $4,7.848$ per cent of variance is explained by factor 5,6.558 per cent of variance is explained by factor 6 and 6.386 per cent of variance is explained by factor 7, these details total variance are explained in Table 3.

\begin{tabular}{|c|c|c|c|c|c|c|c|c|c|}
\hline \multirow[t]{2}{*}{ Component } & \multicolumn{3}{|c|}{ Initial Eigenvalues } & \multicolumn{3}{|c|}{$\begin{array}{c}\text { Extraction Sums of Squared } \\
\text { Loadings }\end{array}$} & \multicolumn{3}{|c|}{$\begin{array}{c}\text { Rotation Sums of Squared } \\
\text { Loadings }\end{array}$} \\
\hline & Total & $\begin{array}{c}\text { Loadings } \\
\% \text { of } \\
\text { Variance }\end{array}$ & $\begin{array}{c}\text { Cumulative } \\
\%\end{array}$ & Total & $\begin{array}{c}\% \text { of } \\
\text { Variance }\end{array}$ & $\underset{\%}{\text { Cumulative }}$ & Total & $\begin{array}{c}\% \text { of } \\
\text { Variance }\end{array}$ & $\underset{\%}{\text { Cumulative }}$ \\
\hline 1. & 3.997 & 19.983 & 19.983 & 3.997 & 19.983 & 19.983 & 2.242 & 11.212 & 11.212 \\
\hline 2. & 1.775 & 8.876 & 28.859 & 1.775 & 8.876 & 28.859 & 2.232 & 11.162 & 22.374 \\
\hline 3. & 1.557 & 7.785 & 36.644 & 1.557 & 7.785 & 36.644 & 1.767 & 8.836 & 31.210 \\
\hline 4. & 1.440 & 7.198 & 43.842 & 1.440 & 7.198 & 43.842 & 1.760 & 8.798 & 40.007 \\
\hline 5. & 1.209 & 6.045 & 49.887 & 1.209 & 6.045 & 49.887 & 1.570 & 7.848 & 47.855 \\
\hline 6. & 1.122 & 5.608 & 55.495 & 1.122 & 5.608 & 55.495 & 1.312 & 6.558 & 54.413 \\
\hline 7. & 1.061 & 5.304 & 60.799 & 1.061 & 5.304 & 60.799 & 1.277 & 6.386 & 60.799 \\
\hline 8. & 0.938 & 4.691 & 65.490 & & & & & & \\
\hline 9. & 0.907 & 4.537 & 70.027 & & & & & & \\
\hline 10. & 0.880 & 4.400 & 74.427 & & & & & & \\
\hline 11. & 0.776 & 3.880 & 78.306 & & & & & & \\
\hline 12. & 0.731 & 3.653 & 81.960 & & & & & & \\
\hline 13. & 0.619 & 3.094 & 85.054 & & & & & & \\
\hline 14. & 0.575 & 2.877 & 87.930 & & & & & & \\
\hline 15. & 0.529 & 2.645 & 90.576 & & & & & & \\
\hline 16. & 0.457 & 2.286 & 92.862 & & & & & & \\
\hline 17. & 0.401 & 2.006 & 94.868 & & & & & & \\
\hline 18. & 0.378 & 1.888 & 96.756 & & & & & & \\
\hline 19. & 0.358 & 1.789 & 98.545 & & & & & & \\
\hline 20. & 0.291 & 1.455 & 100.000 & & & & & & \\
\hline
\end{tabular}

\subsection{Screen Plot}

The researcher can also use the screen plot. In this study, the screen starts with the $7^{\text {th }}$ factor: so, it ${ }^{\text {ee }}$ assumed the seven factors (selected using eigen values over one) have influencing awareness and perception towards equity derivatives. Vol

2021

DOI: $10.53935 / 26415313 . v 4 i 1.172$

Email: selvaraj_naravanan@yahoo.com Funding: This study received no specific financial support.

Received: 17 August 202

Revised: 25 October 2021

Accepted: 12 November 2021

Published: 10 December 2021

(C) 2021 by the authors; licensee Academic Publishing Group

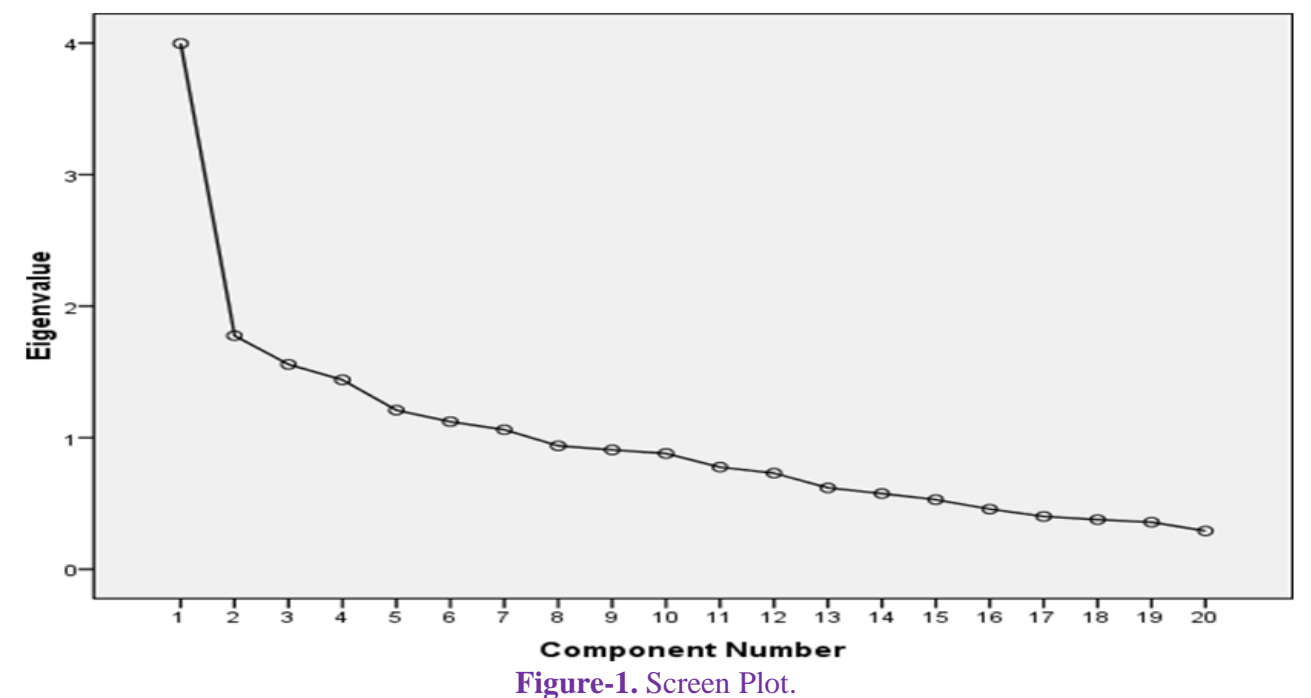




\begin{tabular}{cccccccc}
\multicolumn{10}{c}{ Table-4. Component Transformation Matrix. } \\
\hline Component & $\mathbf{1}$ & $\mathbf{2}$ & $\mathbf{3}$ & $\mathbf{4}$ & $\mathbf{5}$ & $\mathbf{6}$ & $\mathbf{7}$ \\
\hline 1 & 0.548 & 0.535 & 0.316 & 0.397 & 0.335 & 0.209 & 0.026 \\
2 & 0.609 & -0.425 & -0.246 & -0.282 & 0.400 & -0.275 & 0.269 \\
3 & -0.198 & -0.330 & 0.862 & -0.165 & 0.264 & -0.062 & 0.087 \\
4 & -0.205 & 0.621 & -0.031 & -0.633 & 0.181 & -0.136 & 0.344 \\
5 & -0.022 & -0.113 & 0.021 & 0.221 & -0.310 & 0.282 & 0.873 \\
6 & -0.001 & -0.153 & -0.116 & -0.344 & 0.223 & 0.881 & -0.136 \\
7 & -0.497 & -0.051 & -0.285 & 0.410 & 0.692 & -0.040 & 0.143 \\
\hline
\end{tabular}

Note: Extraction Method- Principal Component Analysis. Rotation Method- Varimax with Kaiser Normalization.

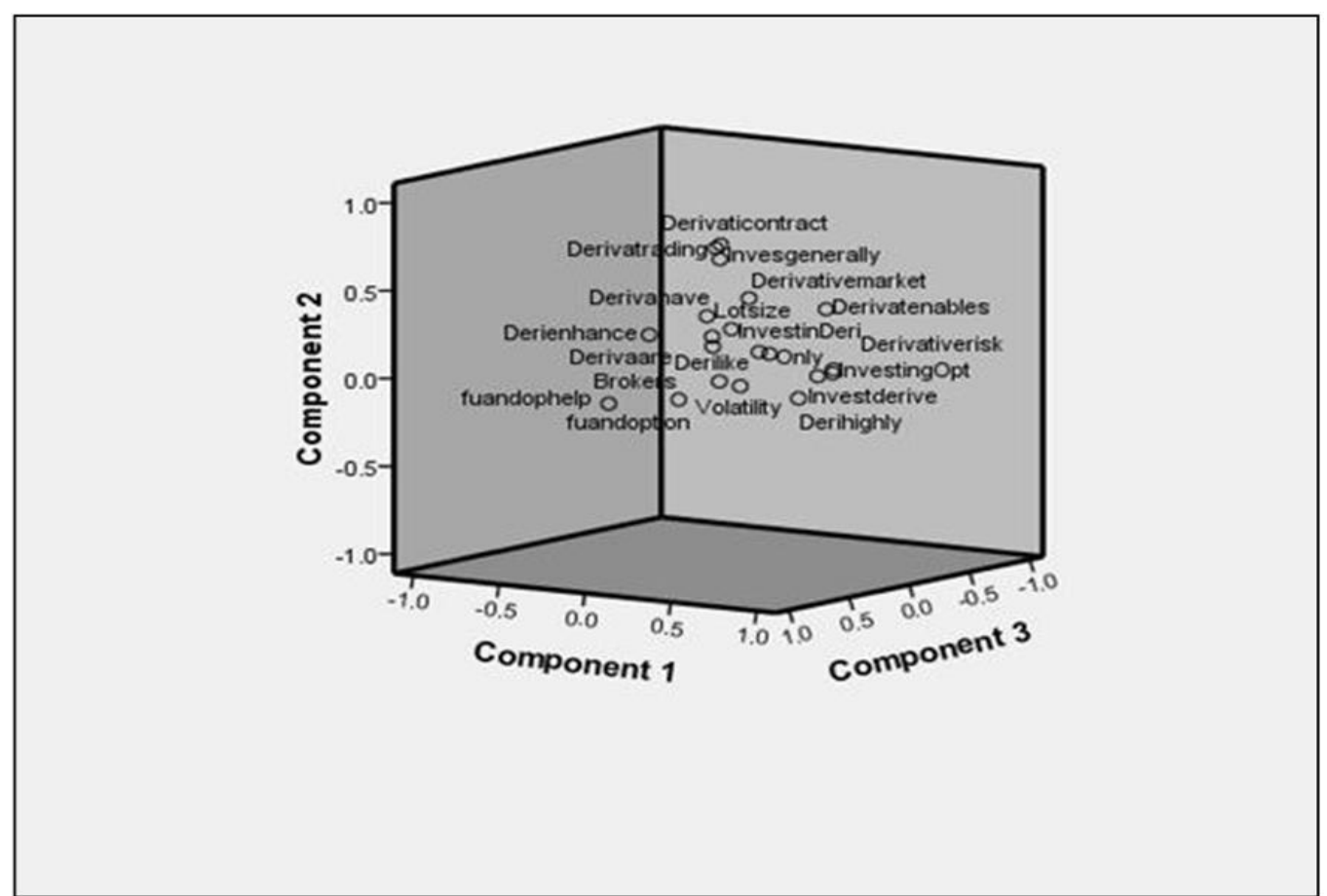

Figure-2. Component Plot Rotated Space.

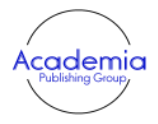

International Journal of Business Management and Finance Research

Vol. 4, No. 1, pp. 19-31

Vol. 4 .

DOI: $10.53935 / 26415313 . v 4 i 1.172$

Email: selvaraj_naravanan@yahoo.com Funding: This study received no specific financial support.

Article History:

Received: 17 August 202

Revised: 25 October 2021

Accepted: 12 November 2021

Published: 10 December 2021

(C) 2021 by the authors; licensee Academic Publishing Group

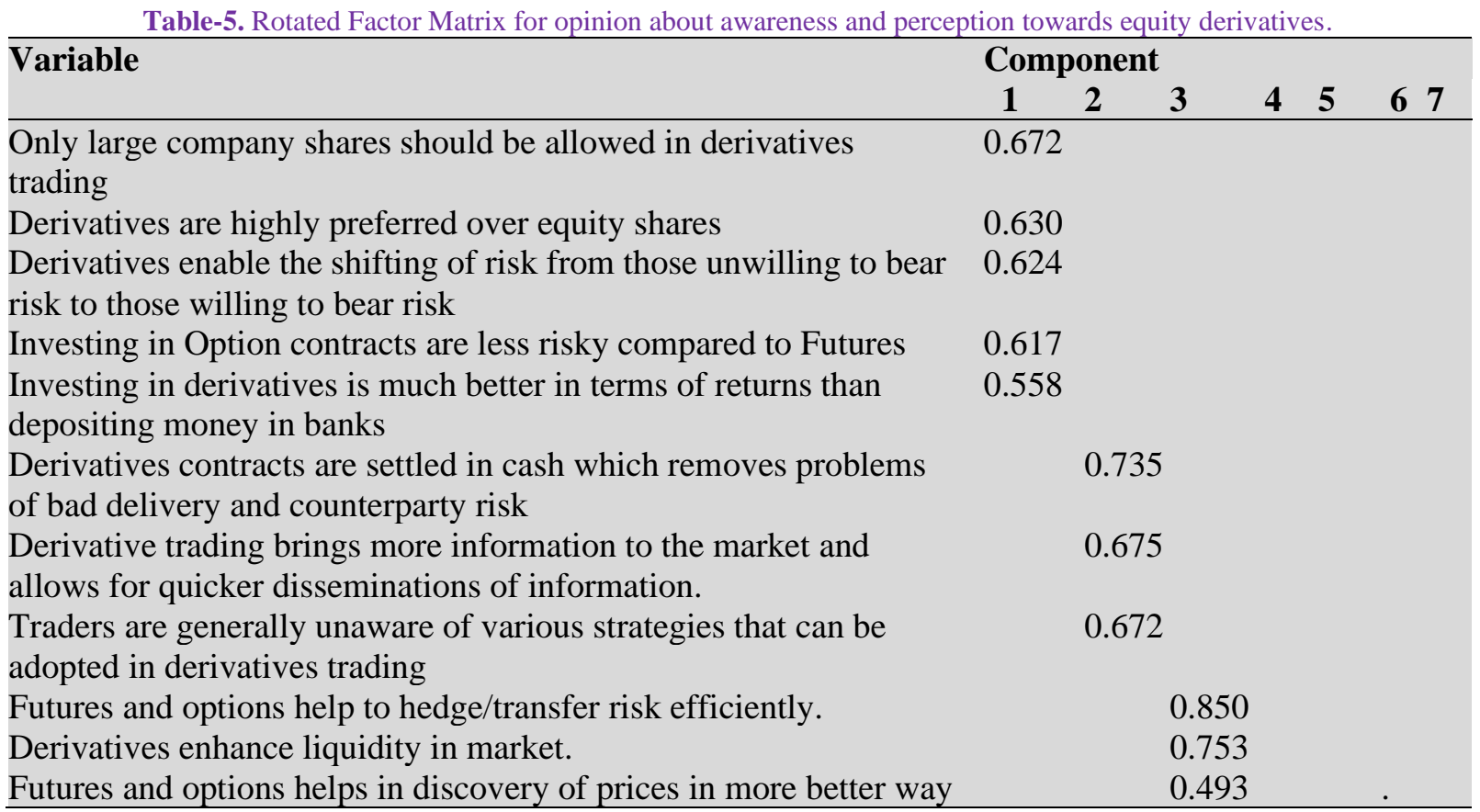


4.6. Rotated Factor Matrix for Factors Influencing the Opinion about Awareness and Perception towards Equity Derivatives (Factor Analysis)

The Rotated Factor Matrix for the variables relating to traders in Madurai District regarding the factors influencing Awareness and Perception towards Equity Derivatives of the overall sample respondents are as follows. Table 5 exhibits the rotated factor loadings for the 20 statements (variables) indicating the Factors influencing the Opinion about awareness and perception towards equity derivatives.

Table-6. Rotated Factor Matrix for opinion about awareness and perception towards equity derivatives - cont...

\begin{tabular}{|c|c|c|c|c|c|}
\hline \multirow[t]{2}{*}{ Variable } & \multicolumn{5}{|l|}{ Component } \\
\hline & $1 \quad 2 \quad 3$ & 4 & 5 & 6 & 7 \\
\hline $\begin{array}{l}\text { Derivatives like Futures and Options are effective risk } \\
\text { management tools }\end{array}$ & & 0.817 & & & \\
\hline Derivative market is properly regulated. & & 0.615 & & & \\
\hline Derivatives are for risk takers and not for conservative traders & & 0.460 & & & \\
\hline Brokers are well educated about Futures & & & 0.691 & & \\
\hline Derivatives are not suitable to small traders & & & 0.642 & & \\
\hline $\begin{array}{l}\text { Lot size of derivative contracts should be reduced to increase } \\
\text { participation in the market. }\end{array}$ & & & & 0.832 & \\
\hline $\begin{array}{l}\text { Volatility has increased in equity market after the } \\
\text { introduction of Futures and Options }\end{array}$ & & & & & 0.821 \\
\hline $\begin{array}{l}\text { Derivatives have the ability to weather the market } \\
\text { fluctuations }\end{array}$ & & & & & 0.447 \\
\hline
\end{tabular}

Table 6 exhibits the rotated factor loadings for the 20 statements (factors) are the factors influencing the Opinion about awareness and perception towards equity derivatives. It is clear from Table 6 that all the 20 statements have been extracted into eight factors namely $F_{1}, F_{2}, F_{3}, F_{4}, F_{5}, F_{6}$, and $F_{7}$. The factors with identified new names which influence the consumer opinion about awareness and perception towards equity derivatives are discussed in the following.

\section{Factor I}

Among the traders opinion about awareness and perception towards equity derivatives, Only large company shares should be allowed in derivatives trading, Derivatives are highly preferred over equity shares, Derivatives enable the shifting of risk from those unwilling to bear risk to those willing to bear risk, Investing in Option contracts are less risky compared to Futures and Investing in derivatives is much better in terms of returns than depositing money in banks are the factors with higher positive loadings on Factor I. The above said five factors with high loadings on Factor I is characterized as "Better earning and Risk". Hence, F1 is termed as Better earning and Risk. The eigen value for the above Factor I is 2.242and the percentage variance is 11.212. It is to be concluded that the traders ${ }^{\text {ee }}$ opinion regarding the derivatives market is getting better earning and also risk along with them. It comes as the first important factor.

\section{Factor II}

The second factor consists of trader opinion regarding the awareness and perception towards equity derivatives such as, "Derivatives contracts are settled in cash which removes problems of bad delivery and counterparty risk, Derivative trading brings more information to the market and allows for quicker disseminations of information and Traders are generally unaware of various strategies that can be adopted in derivatives trading are the factors with higher positive loadings on Factor II. Therefore all the three factors with high loadings on Factor II are characterized as "Proper settlement and getting more information". Hence, F2 is termed as Proper settlement and getting more information. The eigen value for the above Factor II is 2.232and the percentage variance is 11.162 . It is to be concluded that the derivatives contract are cash on proper settlement and derivative trading brings more information and security for the traders. It is the second important factor.

and Finance Research and Finance Research

2021

Email: selvaraj_narayanan@yahoo.com

financial support.

Article History:

Received. 17 August 202

25 October 2021

Published: 10 December 2021

Publishing Group

| 26 
The significant loading statements under third factor $\left(\mathrm{F}_{3}\right)$ are „Futures and options help to hedge/transfer risk efficiently, Derivatives enhance liquidity in market and Futures and options helps in discovery of prices in more better wayare the important factors with higher positive loadings on Factor III. Therefore all the three variables with high loadings on Factor III are characterized as "Transfer of Risk and enhance liquidity". Hence, F3 is termed as Transfer of Risk and enhance liquidity. The eigen value for the above Factor III is 1.767 and the percentage variance is 8.836 . It is to be concluded from the above analysis, that Futures and options help to transfer risk efficiently and enhance liquidity in market.

\section{Factor IV}

The statements made regarding „Derivatives like Futures and Options are effective risk management tools, Derivative market is properly regulated and Derivatives are for risk takers and not for conservative traders are the factors with higher positive loadings on Factor IV. Therefore all the three variables with high loadings on Factor IV are characterized as "Good risk management tool". Hence, F4 is termed as Good risk management tool. The eigen value for the above Factor IV is 1.760 and the percentage variance is 8.798 . It is to be concluded that the Derivatives are effective risk management tools. It comes under fourth important factor.

\section{Factor $V$}

It is understood that the statements made regarding „Brokers are well educated about Futures and Derivatives are not suitable to small traders are the factors with higher positive loadings on Factor V. Therefore the above two variables with high loadings on Factor V are characterized as "Brokers well educated and Derivatives not suitable for small traders". Hence, F5 is termed as Brokers well educated and Derivatives not suitable for small traders. The eigen value for the above Factor IV is 1.570 and the percentage variance is 7.848. It is to be concluded that in derivatives market, the brokers are well educated and also these market not suitable for small traders and it comes under fifth dominant factor.

\section{Factor VI}

The statement made regarding, „Lot size of derivative contracts should be reduced to increase participation in the market" is the factor with another higher positive loadings on Factor V. Therefore, the above variable with high loading on Factor VI is characterized as "Lot size should be reduced". Hence, F6 is termed as Lot size should be reduced. The eigen value for the above Factor IV is 1.312 and the percentage variance is 6.558. It is to be concluded that the Lot size of derivative market contracts should be reduced. Therefore it will lead to increase more number of members participation in the market. It comes under fifth dominant factor.

\section{Factor VII}

It is exhibits from the above statements, ,Volatility has increased in equity market after the introduction of Futures and Options and Derivatives have the ability to weather the market fluctuations are the factors with higher positive loadings on Factor VII. Therefore the above two variables with high loadings on Factor VI are characterized as "More Volatility and Fluctuation". Hence, F7 is termed as More Volatility and Fluctuation The eigen value for the above Factor VII is 1.277 and the percentage variance is 6.386 . It comes under fifth dominant factor.

It is clear from Table 7 that „Only large company shares should be allowed in derivatives trading 0.672 ,

„Derivatives contracts are settled in cash which removes problems of bad delivery and counterparty risk 0.735 ,

„Futures and options help to hedge/transfer risk efficiently 0.850 , „Derivatives like Futures and Options DOI: $10.53935 / 26415313 . v 4 i 1.172$ Email: selvaraj_narayanan@yahoo.com Funding: This study received no specific financial support. Article History:

Received: 17 August 202

Revised: 25 October 2021

Accepted: 12 November 202 derivative contracts should be reduced to increase participation in the market 0.832 and Volatility has increased in equity market after the introduction of Futures and Options0.821 are the variables with the highest factor loadings under factors $F_{1}, F_{2}, F_{3}, F_{4}, F_{5} F_{6}$ and $F_{7}$. Therefore, these are the identified seven variables which influence the traders regarding awareness and perception towards equity derivatives. 
Table-7. Variables with the Highest Factor Loadings for Opinion about Awareness and Perception towards Equity Derivatives.

\begin{tabular}{|c|c|c|c|}
\hline Factor & $\begin{array}{l}\text { Name of newly Extracted } \\
\text { Factor }\end{array}$ & Selected Statement (Variable) & $\begin{array}{l}\text { Factor } \\
\text { Loadings }\end{array}$ \\
\hline$\overline{F_{1}}$ & Better earning and risk & $\begin{array}{l}\text { Only large company shares should be allowed in } \\
\text { derivatives trading }\end{array}$ & 0.672 \\
\hline $\mathrm{F}_{2}$ & $\begin{array}{l}\text { Proper settlement and getting } \\
\text { more information }\end{array}$ & $\begin{array}{l}\text { Derivatives contracts are settled in cash which } \\
\text { removes problems of bad delivery and } \\
\text { counterparty risk }\end{array}$ & 0.735 \\
\hline $\mathrm{F}_{3}$ & $\begin{array}{l}\text { Transfer of risk and enhance } \\
\text { liquidity }\end{array}$ & $\begin{array}{l}\text { Futures and options help to hedge/transfer risk } \\
\text { efficiently. }\end{array}$ & 0.850 \\
\hline $\mathrm{F}_{4}$ & Good Risk management tool & $\begin{array}{l}\text { Derivatives like Futures and Options are effective } \\
\text { risk management tools }\end{array}$ & 0.817 \\
\hline $\mathrm{F}_{5}$ & $\begin{array}{l}\text { Brokers well educated and } \\
\text { Derivatives not suitable for smal } \\
\text { traders }\end{array}$ & Brokers are well educated about Futures & 0.691 \\
\hline $\mathrm{F}_{6}$ & Lot size should be reduced & $\begin{array}{l}\text { Lot size of derivative contracts should be reduced } \\
\text { to increase participation in the market. }\end{array}$ & 0.832 \\
\hline $\mathrm{F}_{7}$ & $\begin{array}{l}\text { More Volatility and } \\
\text { Fluctuation }\end{array}$ & $\begin{array}{l}\text { Volatility has increased in equity market after the } \\
\text { introduction of Futures and Options }\end{array}$ & 0.821 \\
\hline
\end{tabular}

4.7. Multiple Regressions

H1: Gender Wise Classification of the Respondents, Age Wise Classification of Respondents, Educational Qualification, Occupation, Annual income of the family, Marital Status, Mode of trade and amount of investment in derivatives.

\begin{tabular}{lcccc}
\hline \multicolumn{4}{c}{ Table-8. Model Summary. } \\
\hline Model & R & R Square & Adjusted R Square & Std. Error of the Estimate \\
\hline 1 & $0.434^{\text {a }}$ & 0.189 & 0.166 & 0.93835 \\
\hline $\begin{array}{l}\text { Note: a. Predictors: (Constant), Amount of investment in derivatives, Educational Qualification, Age Wise Classification of } \\
\text { Respondents, Marital Status, Gender Wise Classification of the Respondents, Annual income of the family, Occupation, Mode of } \\
\text { trade }\end{array}$
\end{tabular}

The above model summary Table shows R-square for this model is means that R-square for this this model is 0.189 . This means that $18.9 \%$ of the variation in the level of satisfaction of customers (dependent variable) can be explained from the 11 independent variables. Table also shows the adjusted R-square for the model as 0.166 .

\begin{tabular}{ccccccc}
\multicolumn{10}{c}{ Table-9. ANOVA } \\
\hline & Model & Sum of Squares & Df & Mean Square & F & Sig. \\
\hline 1 & Regression & 59.572 & 8 & 7.447 & 8.457 & 0.000 \\
& Residual & 256.225 & 291 & 0.880 & & \\
& Total & 315.797 & 299 & & & \\
\hline
\end{tabular}

$\mathrm{F}$ test of the model shows that the model is significant as the significant of $\mathrm{F}$ is $0.05(0.000)$ which is less than 0.05 , Hence, the null hypothesis $\left(\mathrm{H}_{\mathrm{O}}\right)$ is rejected (the p-value indicates the significance of the $\mathrm{F}$ value).

To determine if one or more of the independent variables are significant predictors of Derivative options of the traders, to examine the information provided in the coefficient table. From the above 8 independent statements, there are three statements are not statistically significant. The standardized coefficient beta column reveals the Gender Wise Classification of the Respondents has a beta coefficient -.136, which is significant (0.015).Age Wise Classification of Respondents has a beta coefficient .162, which is significant (0.004).Educational Qualification of the Respondents has a beta coefficient .141, which is significant (0.011). Annual income of the family has a beta coefficient -.146, which is significant (0.012). Marital Status of the Respondents has a beta coefficient .293, which is significant (0.001),occupation has a beta coefficient .018 , which is not significant (.756). Mode of trade has a beta coefficient 0.149 , which is not significant

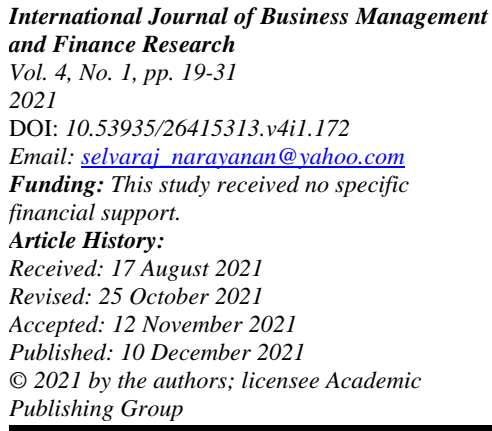


(0.095), and Amount of investment in derivatives has a beta coefficient .116, which is not significant (0.061).From the above Table 4.60, it can be concluded that Marital Status, Age Wise Classification of Respondents, Educational Qualification, Annual income of the family and Gender Wise Classification of the Respondents are having major impact on the selection of Derivative options of the Respondents compared to other factors.

\begin{tabular}{|c|c|c|c|c|c|c|}
\hline & & Co-eff & ient ${ }^{a}$ & & & \\
\hline & & Unsta & adardized & $\begin{array}{l}\text { Standar-dized } \\
\text { Coeffi-cients }\end{array}$ & $\mathbf{t}$ & Sig. \\
\hline & & B & Std. Error & Beta & & \\
\hline 1 & (Constant) & 1.944 & 0.494 & & 3.936 & 0.000 \\
\hline & $\begin{array}{l}\text { Gender Wise Classification of } \\
\text { the Respondents }\end{array}$ & -0.316 & 0.129 & -0.136 & -2.449 & 0.015 \\
\hline & $\begin{array}{l}\text { Age Wise Classification of } \\
\text { Respondents }\end{array}$ & 0.172 & 0.060 & 0.162 & 2.871 & 0.004 \\
\hline & Educational Qualification & 0.181 & 0.071 & 0.141 & 2.545 & 0.011 \\
\hline & Occupation & -0.013 & 0.042 & -0.018 & -0.311 & 0.756 \\
\hline & Annual income of the family & -0.230 & 0.091 & -0.146 & -2.537 & 0.012 \\
\hline & Marital Status & 0.610 & 0.184 & 0.293 & 3.310 & 0.001 \\
\hline & Mode of trade & -0.329 & 0.196 & -0.149 & -1.673 & 0.095 \\
\hline & $\begin{array}{l}\text { Amount of investment in } \\
\text { derivatives }\end{array}$ & 0.120 & 0.064 & 0.116 & 1.879 & 0.061 \\
\hline
\end{tabular}

\section{Findings}

„Only large company shares should be allowed in derivatives trading 0.672, „Derivatives contracts are settled in cash which removes problems of bad delivery and counterparty risk 0.735 , „Futures and options help to hedge/transfer risk efficiently 0.850 , „Derivatives like Futures and Options are effective risk management tools0.817. Brokers are well educated about Futures0.691, Lot size of derivative contracts should be reduced to increase participation in the market 0.832 and Volatility has increased in equity market after the introduction of Futures and Options 0.821 are the variables with the highest factor loadings under factors F1, F2, F3, F4, F5,F6andF7. Therefore, these are the identified seven variables which influence the traders awareness and perception towards equity derivatives. The model is significant as the significant of $\mathrm{F}$ is $0.05(0.000)$ which is less than 0.05 , Hence, the null hypothesis (Ho) is rejected (the p-value indicates the significance of the $\mathrm{F}$ value). The standardized coefficient beta column reveals the Gender Wise Classification of the Respondents has a beta coefficient -0.136, which is significant (0.015).Age Wise Classification of Respondents has a beta coefficient 0.162, which is significant (0.004).Educational Qualification of the Respondents has a beta coefficient 0.141 , which is significant (0.011).Annual income of the family has a beta coefficient -0.146, which is significant (0.012). Marital Status of the Respondents has a beta coefficient 0.293, which is significant (0.001), occupation has a beta coefficient -.018 , which is not significant (0.756). Mode of trade has a beta coefficient 0.149, which is not significant (0.095), and Amount of investment in derivatives has a beta coefficient 0.116 , which is not significant (0.061).From the above table it can be concluded that Marital Status, Age Wise Classification of Respondents, Educational Qualification, Annual income of the family and Gender Wise Classification of the Respondents are having major impact on the selection of Derivative options of the Respondents compared to other factors.

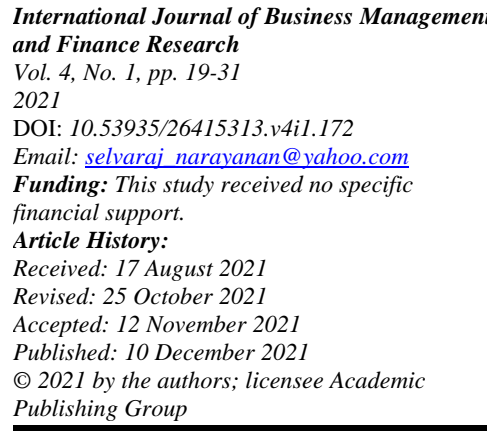

\section{Suggestions}

Following are the consolidated list of suggestions for the purpose.

1. Since people don't prefer to invest in Indian Stock Market owing to lack of their knowledge on the Market and prospects of this mode of investment, it is necessary to drive awareness campaigns by the regulatory bodies and brokerage houses with the backing of the government.

2. In order to counter negative word of mouth, successful traders are to be encouraged and motivated to air their success stories at different forums. 


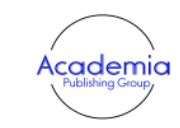

International Journal of Business Management and Finance Research Vol. 4 , No. 1, pp. 19-31 Vol. 4 .

DOI: $10.53935 / 26415313 . v 4 i 1.172$

Email:selvaraj_narayanan@yahoo.com

Funding: This study received no specific

financial support.

Article History:

Received: 17 August 202

Revised: 25 October 2021

Accepted: 12 November 2021

Published: 10 December 2021

(C) 2021 by the authors; licensee Academic Publishing Group
3. Since people have fear of being cheated, workshops to train the potential traders to have knowledge on how to trade by own.

4. A mechanism may be developed to ensure the traders that the investment could be channelized by the brokerage houses with some sort of assurance of a considerable percentage of principal amounts so that people having no time to trade by their own could depend on the brokerage houses with confidence.

5. The concept of General Insurance may be extended to the amount invested in Indian Stock Market for which the premium may be collected from the traders.

6. To keep the interest of the traders in mutual fund the companies will play a vital role to attract the traders to invest in mutual fund so for that companies should bring such plans which is having very low risk

7. As per the study the traders wants safe returns on their investment and all traders know the risk in share market and which is the main reason traders avoid to invest in shares and equities or mutual fund because of the fear of losing the money

8. The Market should maintain a good relationship in reality and should render of quick services according to the customers, in case of necessity.

9. The Capital market should go for doorstep services, which would help the customers to get educated regarding the services and be the prospective customers.

10. The Capital market should have a separate customer"s care department so that they keep in touch with customers which make them feel they are cared loved needed.

11. Public awareness can be through any media, but we see that the awareness is through the customers of the Capital market through advertisement which would more the company feel great and even it can reduce its promotional costs and time.

12. The brokers of the stock broking company should be profit centered than brokerage centered for their customers.

13. There is a need to spread more awareness among the existing and potential traders.

14. Findings of the study suggest that more efforts are needed to spread awareness, especially among the women. This is because of their lower participation compared to the equity assets under their ownership.

15. These finding provide a great opportunity for intermediaries and asset management companies to target and market equity asset instruments to enhance participation and exposure.

16. Asset management companies should design more products with capital protection element as the most retail traders perceive „capital erosion" as the top risk while investing in equity assets. Based on the given finding, regulators can also think of some insurance scheme that protects capital of the beginners or small traders to boost participation.

17. It has been established that traders" risk to return perceptions are vastly different and depend on demographic variables. Market players should leverage the findings of this study and help traders in fulfilling their investment objectives and goals.

18. Investment experience of the traders in the market is a crucial variable that has a significant impact on investment decisions. Intermediaries and brokers should take cognizance of this finding and leverage it to customize their offerings appropriately for traders.

19. Among several mutual fund schemes, retail traders" top choice is to invest in "growth funds". On the other hand ,index funds" are the least preferred. Asset management companies should consider these preferences for designing and selling mutual fund products.

20. Two leading stock exchanges have introduced 75 different meaningful indices. However, still SENSEX and NIFTY are the most preferred indices for retail traders. More awareness needs to be spread for the newer indices as they are useful indicators of sectorial performance.

21. More traders prefer corporate and online over traditional brokers/intermediaries. Traditional brokers should adopt technology and modern ways, not only to grow but sustain their share in the market.

22. It is found that majority of the traders still prefer newspapers and business channels on TV as a medium to access investment information. Hence it is essential for the market players to continue using these mediums for spreading awareness. India is not yet ready to bypass these traditional mediums for websites and Apps.

23. The Technological up gradation such as online trading, online consultation of stockbrokers and online 


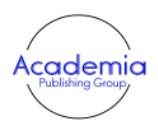

International Journal of Business Management and Finance Research Vol. 4, No. l, pp. 19-31 2021

DOI: $10.53935 / 26415313 . v 4 i 1.172$

Email:selvaraj_narayanan@yahoo.com

Funding: This study received no specific

financial support.

Article History:

Received: 17 August 202

Revised: 25 October 2021

Accepted: 12 November 202

Published: 10 December 2021

(C) 2021 by the authors; licensee Academic

Publishing Group availability of audited annual reports should be introduced in capital market for its growth and to attract traders.

24. Risk minimizing strategies like hedging, stock index futures and stock index options should be introduced in capital market so as to attract rational traders

25. The study suggests that Government should look forward to setting up a super regulator who can take care of these various regulatory arbitrage/risk issues or there should be joint committee of all the regulatory bodies to look into such concerns of the market from overall perspective.

26. This study can be used by the regulating authorities and broker houses to increase awareness among the traders about derivatives.

27. One should invest in secured and risk-free investments rather than high-risk, highly profitable investments.

28. Tracking the market environment better with sound knowledge about a particular stock would result in better returns.

29. Since many of the entities in this study are independent of each other, there is need to analyse on a buying decision specifically for respective stocks

30. People with less experience can also be high profit makers when decisions are based on intricate fundamental and technical analyses.

31. The Awareness programmes should be conducted at various places in order to attract women traders.

32. The Awareness regarding equity derivatives should be spread in rural areas because those people are financially stable but they have no knowledge to invest their surplus funds.

33. Traders are the life blood of the capital market, so safety, profitability and liquidity of their funds should be ensured.

\section{Conclusion}

The success of a country"s economy largely depends upon the growth of the capital market to and the growth of the capital market depends upon the proper understanding of the small individual traders (Household) and attracting them towards the capital market, the reason is that all the individual traders have got the major chunk to invest as they have got more than what the spent and this holds quite opposite in case of all corporate entities. The Derivatives are financial contracts whose value is derived from some underlying asset. These assets can include equities and equity indices, bonds, loans, interest rates, exchange rates, commodities. The contracts come in many forms, but the more common ones include options, forwards/futures and swaps. This study has been to trader compare among different types of derivatives for reducing risk and increase the return. This is important if one wants to understand the determinants of use of each type of derivatives, due to the fact that traders of derivatives often use more than one type of derivatives. Modern traders are rapidly informed than their predecessors. Modern traders want future security while investing. So, every stockbrokerage agency should make their strategies for the benefit of the traders on a long term basis. This study would be of great use for traders and financial intermediaries who make decisions regarding investment. This study will help the traders and investment consultants in identifying profitable investment avenues. Traderes preference for equity will help the policymakers in formulating strategies and will also help the credit rating agencies in rating the investment instruments. Stock exchanges can introduce technological advancement in trading. In short, this piece of research is of immense use for all the three group of players in the capital market viz. the traders, issuers and the intermediaries.

\section{References}

Baker, M., Wurgler, J., \& Yuan, Y. (2012). Global, local, and contagious investor sentiment. Journal of Financial Economics, 104(2), 272-287.

Sehgal, S., Sood, G. S., \& Rajput, N. (2009). Trader sentiment in India: A survey. Vision-The Journal of Business Perspectivess, 13(3), $13-23$.

Somanathan, T. V. (2003). Derivatives. New Delhi: Tata McGraw-Hill Publishing Company Limited.

Srivastava, S. S., Y. S., \& Jain, P. K. (2008). Derivative trading in Indian stock market brokers perception. IIMB Management Review, 20(3), 311-323.

Venkatesha, R., \& Hiriyappa, B. (2017). Traders perception towards derivative Market with special reference to shivamogga. Acme Intellects International Journal of Research in Management, Social Sciences and Technology, 19(19). 